\title{
Ihtikar dan Tas'ir dalam Kajian Hukum Bisnis Syariah
}

\author{
Ahmad Zaini \\ Institut Agama Islam Negeri Kudus \\ zaini78@stainkudus.ac.id
}

\begin{abstract}
We have heard news on television about the depletion of the availability and even the disappearance of food and gas in several regions. This causes the price of rice and gas to rise. As a result, there were long queues in these areas to buy rice (the price of which was quite affordable). Likewise with gas, the gas tube queues that are lined up become a common sight. The incident, not infrequently some sellers carry out hoarding actions or often referred to as monopolies. Broadly speaking, the attitude of the jurists regarding ihtikār includes several groups, groups that see that ihtikar is an act of haram, makruh, mubah and mandub. Ihtikar and tas'ir can be done if the price situation in the market soars. Of course, those who have the right to control monopoly and pricing are the authorities with the conditions for the benefit of the people. Monopoly and pricing basically harm many people, but both can be enforced under forced conditions and prices are not stable. Keywords: Ihtikar, Tas'ir, Syari'ah Business
\end{abstract}

\begin{abstract}
Abstrak
Kita pernah mendengar berita di televisi tentang menipisnya ketersediaan bahkan menghilangnya ketersediaan bahan makanan dan gas di beberapa daerah. Hal tersebut menyebabkan harga beras dan gas menjadi naik. Akibatnya, di daerahdaerah tersebut terjadi antrian yang cukup panjang untuk membeli beras (yang harganya cukup terjangkau). Begitu juga dengan gas, antrian tabung gas yang berjajar menjadi pemandangan yang biasa. Kejadian tersebut, tidak jarang sebagian penjual melakukan tindakan penimbunan atau yang sering disebut dengan monopoli. Secara garis besar sikap ahli fikih mengenai ihtikār meliputi beberapa kelompok, kelompok yang memandang bahwa ihtikar merupakan perbuatan haram, makruh, mubah dan mandub. Ihtikar dan tas'ir bisa dilakukan jika keadaan harga di pasaran melonjak tinggi. Tentunya, yang lebih berhak mengendalikan monopoli dan penetapan harga adalah penguasa dengan syarat untuk kemaslahatan orang banyak. Monopoli dan penetapan harga pada dasarnya merugikan orang banyak, namun keduanya dapat diberlakukan dalam keadaan terpaksa dan harga tidak stabil.
\end{abstract}

Kata Kunci: Ihtikar, Tas'ir, Bisnis Syari'ah

\section{PENDAHULUAN}

Kita pernah mendengar kabar mengenai terjadinya kekurangan bahan makanan pokok, bahan bakar minyak, ketersediaan pasokan gas untuk memasak, dan berita-berita lain yang terkait dengan menipisnya ketersediaan kebutuhan pokok. Seringkali hilangnya kebutuhan pokok ini 
sedemikian parahnya, hingga menimbulkan pemandangan antrian yang cukup panjang.

Semisal kita pernah mendengar hilangnya ketersediaan beras di beberapa daerah dan hilangnya pasokan gas. Hal tersebut menyebabkan harga beras dan gas menjadi naik. Akibatnya, di daerah-daerah tersebut terjadi antrian yang cukup panjang untuk membeli beras (yang harganya cukup terjangkau). Begitu juga dengan gas, antrian tabung gas yang berjajar menjadi pemandangan yang biasa. Bila kita gambarkan, misalnya bahan bakar gas menghilang dari pasaran, maka harga gas yang sebelum mereka timbun, katakanlah seharga $\mathrm{Rp} 3500 / \mathrm{kg}$, setelah mereka timbun (yang berakibat harga gas naik) harganya naik menjadi lebih dari Rp 4500/kg. Begitu juga dengan harga barang-barang lainnya.

Untuk itu perlu dibuat peraturan yang mampu mengayomi hajat hidup orang banyak. Dalam hal ini, bagaimanakah pandangan Islam tentang penimbunan (monopoli)? Bolehkah menimbun barang yang dibutuhkan masyarakat? Dan kalau tidak boleh, adakah pengecualian yang dapat dilakukan? Semisal penimbunan beras yang dilakukan oleh pemerintah yang diwakili oleh Bulog sehingga dapat mematok harga?

Islam datang ingin menegakkan keadilan di bawah naungan norma pasar. Kemanusiaan yang besar menghormati yang kecil, yang kuat membantu yang lemah, yang bodoh belajar dari yang pintar, dan manusia menentang kezaliman.

\section{KAJIAN LITERATUR \\ Definisi Monopoli}

Monopoli dalam bahasa Arab disebut ihtikär. Dalam kamus-kamus bahasa Arab ihtikār mempunyai arti yang banyak, diantaranya sebagai berikut: menurut az-Zamakhsyari adalah احتكر الطعام: احتبسه للغلاء (ihtakära attha'ām artinya: menimbun makanan sehingga harganya naik).

Ibnu Manzur mengartikanya sebagai berikut الاحْتَكَارُ جمع الطعام ونحوه ممان

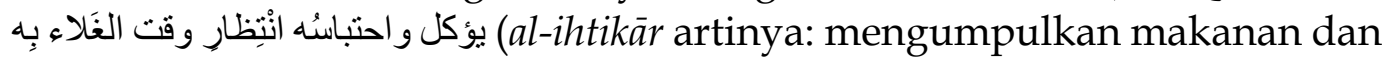
yang sejenisnya dari apa-apa yang dimakan dan menahannya dengan menunggu naiknya harga).

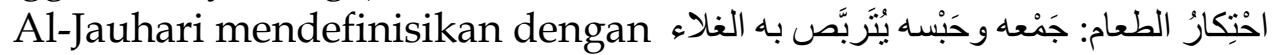
(ihtikār at-ta'ām artinya: mengumpulkan dan menimbun dengan menunggu harganya naik).

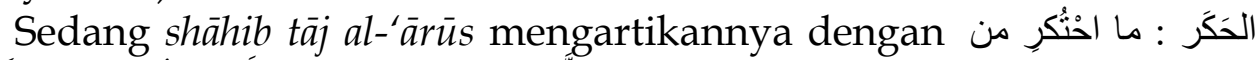
(al-hakar artinya: mengumpulkan makanan dan yang sejenisnya dari apa-apa yang dimakan dan menahannya dengan menunggu naiknya harga), dan masih banyak lagi. (al-Maktabah Syamilah) 
Ulama fikih berbeda pendapat mengenai definisi tentang hakikat ihtikār yang jumlahnya lebih dari duapuluh pendapat. Perbedaan pendapat ini tidak terbatas atas mazhab-mazhab yang ada, tetapi di dalam satu mazhab mereka juga berselisih tentang definisinya. Perbedaan ini dikarenakan mereka mempunyai sistem dan metode yang berbeda dalam memahami hukum.

Pertama, menurut Hanafiyah ihtikār diartikan dengan penimbunan bahan makanan sehingga harganya melonjak tinggi. Kedua, menurut Syafi'iyah ihtikār adalah membeli bahan makanan waktu harganya tinggi dan menyimpannya, kemudian menjualnya dengan harga diatas normal, sehingga menyulitkan orang banyak. Ketiga, menurut Malikiyah ihtikār ialah penimbunan barang yang dijual, karena dengan menyimpannya akan memperoleh keuntungan disebabkan harga di pasaran tidak stabil. Keempat, menurut Ibnu Hazm az-Zahiri ihtikār yaitu penimbunan yang membahayakan manusia adalah haram baik itu dalam pembelian dan menahan barang yang dijual. Kelima, ihtikār menurut Imamiyah adalah mengumpulkan dan menimbun bahan makanan dengan menunggu harganya membumbung. Keenam, menurut Yusuf Qaradawi ihtikār ialah menahan barang dari perputaran di pasar sehingga harganya naik. (Yusuf Qardawi, 1997: 190)

Monopoli dalam undang-undang Republik Indonesia Nomor 5 Tahun 1999 tanggal 5 Maret 1999 Bab I Pasal 1 didefinisikan sebagai penguasaan atas produksi dan atau pemasaran barang dan atau atas penggunaan jasa tertentu oleh satu pelaku atau satu kelompok pelaku usaha. (Gunawan Widjaja, 2000: 94) Pengertian monopoli dalam Kamus Besar Bahasa Indonesia yang dimaksud adalah situasi yang pengadaan barang dagangannya tertentu (di pasar lokal atau nasional) sekurangkurangnya sepertiganya dikuasai oleh satu orang atau satu kelompok, sehingga harganya dapat dikendalikan. (Depdikbud, 1996: 664)

Dari pengertian-pengertian di atas dapat disimpulkan bahwa ihtikār (monopoli) adalah menyimpan barang-barang yang dibutuhkan orang banyak baik dilakukan oleh satu orang atau satu kelompok dengan tujuan menjualnya kembali di atas harga normal serta dapat mengendalikan harganya sehingga memperoleh keuntungan yang banyak.

\section{Hukum Monopoli}

Ulama fikih berbeda pendapat mengenai hukum ihtikār antara haram dan makruh. Mereka tidak bersepakat tentang definisi hakikat ihtikār yang jumlahnya lebih dari duapuluh pendapat. Perbedaan pendapat ini tidak terbatas atas mazhab-mazhab yang ada, tetapi di dalam satu mazhab mereka juga berselisih tentang definisinya. Perbedaan ini 
dikarenakan mereka mempunyai sistem pemahaman hukum yang berlainan. (Ahmad Mustafa, 2003: 102)

Pendapat pertama, dikemukakan oleh ulama mazhab Hanafi, Maliki, Jumhur ulama Syafi'i, Hanbali, az-Zahiri, Zaidiyah, Abadiyah dan kebanyakan Imamiyah. Menurut mereka melakukan ihtikār hukumnya haram. (Ahmad Mustafa, 2003: 102)Dasar hukum pelarangan ihtikār yang mereka kemukakan adalah hasil induksi dari nilai-nilai universal yang dikandung Al-Qur`an yang menyatakan, bahwa setiap perbuatan aniaya, termasuk di dalamnya ihtikār, diharamkan. (Abdul Aziz, 1996: 655) Mereka mengemukakan alasan tentang haramnya ihtikār berdasarkan ayat AlQur`an dan hadis berikut ini.

1. Pertama, dasar pengharaman ihtikār menurut Al-Qur`an terdapat dalam surat al-Haj ayat 25.

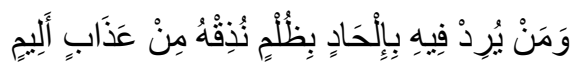

Artinya: "Dan siapa yang bermaksud di dalamnya melakukan kejahatan secara zalim, niscaya akan Kami rasakan kepadanya sebahagian siksa yang pedih" (QS. Al-Haj: 25).

Ayat ini menjelaskan bahwa ihtikār adalah haram. Karena ihtikār adalah perbuatan zalim dan aniaya. Dan berbuat zalim adalah dilarang. Perbuatan zalim jika dilakukan akan menyebabkan seseorang mendapat siksa yang pedih. Orang yang mendapat siksa yang pedih adalah karena melakukan hal yang dilarang. Maka dari itu ihtikār adalah haram. Ulama mengatakan pada dasarnya bahwa ayat di atas di sebagian maknanya berfungsi untuk mengharamkan ihtikār .

2. Kedua, dalil-dalil yang berdasarkan dari hadis.

a. Hadis-hadis yang bersifat mutlak.

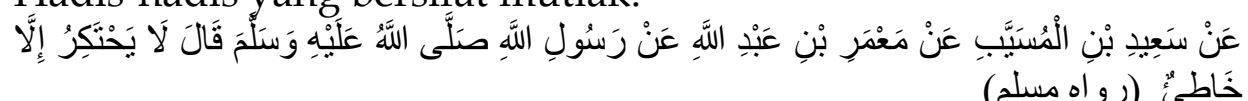

"Dari Sa'id bin Musayyab dari Ma'mar bin Abdullah dari Rasulullah SAW bersabda: Tidak akan melakukan penimbunan selain orang yang salah" (HR. Muslim).

Istinbāt hukum dari hadis ini adalah tidak bolehnya melakukan ihtikār, karena dijelaskan bahwa muhtakir (orang yang menimbun) adalah orang yang salah, disebut juga dengan 'äshin (orang yang bermaksiat) dan orang yang bersalah adalah mudznib (orang yang berdosa). Pada zahirnya hadis ini menerangkan bahwa ihtikār adalah haram tanpa dibedakan antara makanan manusia, makanan hewan dan lainnya. Kebanyakan ulama berpendapat bahwa yang diharamkan adalah bahan makanan saja. Alasannya, di sebagian hadis hanya disebutkan kata "tha' âm".

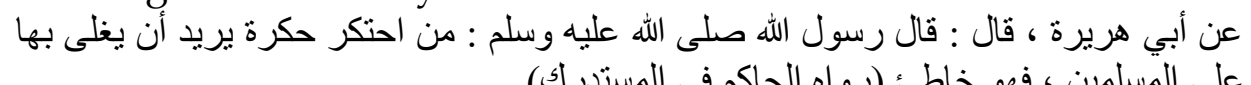

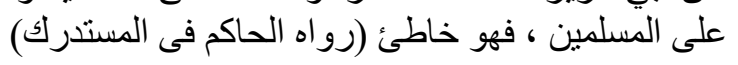


Dari Abu Hurairah berkata: Rasulullah SAW bersabda: "Barang siapa yang melakukan penimbunan dengan maksud agar harganya melonjak, maka dia orang yang salah" (HR. Hakim).

Hadis ini menerangkan bahwa orang yang menimbun dengan maksud supaya harganya melonjak tinggi maka ia adalah orang yang salah dan Allah telah melepaskan naungan darinya".

b. Hadis-hadis yang bersifat muqayyad.

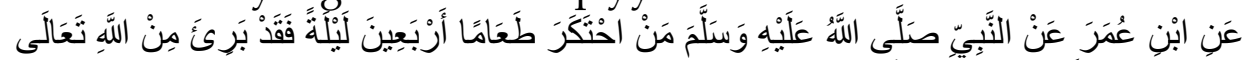

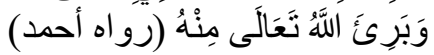

Dari Ibnu Umar dari Nabi SAW: "Barang siapa menimbun makanan selama empat puluh malam maka terlepas dari naungan Allah dan Allah melepaskan naungan darinya" (HR. Ahmad).

روى أبو أمامة الباهلى أن النبى صلى الله عليه وسلم نهى أن يحتكر الطعام (رواه الحاكم فى

المستدرك)

"Abu Umamah al-Bahili meriwayatkan bahwa Nabi SAW telah melarang penimbunan makanan" (HR. Hakim).

Lafal umum kedua hadis ini menunjukkan atas haramnya ihtikār, dan sesungguhnya azab di neraka, ancaman dan laknat, tidaklah ada kecuali bagi orang yang melakukan hal-hal yang haram. (Ahmad Mustafa, 2003: 103-106)

Syarat-syarat ihtikār yang diharamkan di antaranya:

1) Menimbun dengan menunggu waktu harganya tinggi.

2) Menimbun pada waktu yang dibutuhkan.

3) Sesuatu yang ditimbun melebihi kebutuhannya.

4) Sesuatu yang ditimbun adalah barang yang dibeli.

5) Sesuatu yang ditimbun adalah bahan makanan.

6) Menimbun pada waktu tertentu. (Ahmad Mustafa, 2003: 120)

Pendapat kedua, dianut oleh sebagian pengikut Syafi'i, Isma'iliyah dan sebagaian Imamiyah. Menurut mereka ihtikār adalah makruh. Alasannya, seseorang mempunyai kekuasaan atas hartanya dan mereka bebas melakukan jual beli yang sesuai dengan kehendak mereka. (Ahmad Mustafa, 2003: 108)

\section{PEMBAHASAN}

Sikap Ahli Fikih tentang Ihtikār yang Makruh, Ja iz dan Mandub

Secara garis besar sikap ahli fikih mengenai ihtikār adalah sebagai berikut.

Syarat-syarat ihtikār makruh:

1. Menimbun tanpa tujuan menunggu harga tinggi.

2. Menimbun pada waktu barang itu banyak.

3. Menimbun untuk keperluannya dan keluarganya. 
Para ulama berbeda pendapat antara makruh dan haram bagi seseorang yang menimbun makanan dan pakaian, masing masing mempunyai dalil, jika terpenuhi syarat-syarat haram maka hukumnya haram, dan jika tidak maka hukumnya makruh.

Menimbun yang diperbolehkan atau mubah yaitu:

1. Menimbun sesuatu tanpa tujuan untuk menjualnya.

2. Boleh menimbun manisan, minyak, dan makanan hewan.

Keadaan diperbolehkannya menimbun:

1. Menimbun pada waktu yang lapang.

2. Seseorang menyimpan untuk kebutuhannya dan keluarganya.

3. Menimbun di negara yang penduduknya musyrik.

Menimbun yang mandub yaitu jika menimbun untuk kemaslahatan umum, seperti dijelaskan oleh Subkhi, Qadi Husain, Royani dan Khamili bahwasanya jika harga barang itu sedang murah dan barang itu tidak sedang dibutuhkan masyarakat, maka tidak dilarang untuk menimbun sampai barang itu dibutuhkan, dan hal ini baik karena bermanfaat bagi masyarakat. (Ahmad Mustafa, 2003: 120-167)

\section{Jenis Produk Ihtikār}

Definisi-definisi di atas berbeda tentang jenis produk yang disimpan atau ditimbun di gudang, sekalipun dalam esensi ihtikār tersebut memiliki pengertian yang sama yaitu menyimpan barang-barang yang dibutuhkan masyarakat dengan tujuan menjualnya ketika harga telah melonjak, barang itu baru dipasarkan.

Ulama Mazhab Maliki, sebagian ulama Mazhab Hanbali, Imam Abu Yusuf dan Abidin menyatakan bahwa larangan ihtikār tidak terbatas pada makanan, pakaian dan hewan, tetapi meliputi seluruh produk yang dibutuhkan masyarakat. Menurut mereka yang menjadi 'illat (motivasi hukum) dalam larangan melakukan ihtikār tersebut adalah kemudaratan yang menimpa orang banyak. Oleh sebab itu, kemudaratan yang menimpa orang banyak tidak terbatas pada makanan, pakaian dan hewan, tetapi mencakup seluruh produk yang dibutuhkan orang. (Abdul Aziz, 1996: 654)

Senada dengan pendapat Mazhab Maliki, sebagian ulama Mazhab Hanbali, Imam Abu Yusuf dan Abidin, Yusuf Qaradawi mengatakan bahwa dilarang melakukan monopoli terhadap semua jenis barang yang dibutuhkan oleh manusia, baik itu makanan, obat-obatan, pakaian, perlengkapan sekolah, perabot rumah tangga, atau perabot kantor. Alasannya adalah umumnya lafal atau redaksi hadis yang berbunyi "Tidak ada seorangpun yang memonopoli kecuali orang-orang yang bersalah". Jadi, intinya, barang siapa melakukan monopoli, ia berdosa. Redaksi hadis ini bersifat umum, sedangkan nash tentang pelarangan monopoli yang 
dikhususkan terhadap makanan saja bersifat khusus. Redaksi yang khusus tidak bisa menafikan redaksi yang umum. (Yusuf Qardawi, 1997: 191)

Sebagian ulama Mazhab Hanbali dan Imam al-Gazali mengkhususkan keharaman ihtikār pada jenis produk makanan saja. Alasannya, karena yang dilarang dalam nash hadis hanyalah makanan. Menurut mereka, karena masalah ihtikār menyangkut kebebasan pemilik barang untuk menjual barangnya dan kebutuhan orang banyak, maka larangan itu harus terbatas pada apa yang ditunjuk oleh nash saja. (Abdul Aziz, 1996: 655)

Sedangkan ulama dari kalangan Mazhab Syafi'i dan Hanafi membatasi ihtikār pada komoditas yang berupa makanan bagi manusia dan hewan. Menurut mereka, komoditas yang terkait dengan kebutuhan orang banyak pada umumnya hanya dua jenis ini. Oleh sebab itu, perlu dibatasi. (Abdul Aziz, 1996: 655)

\section{Rekayasa Pasar dalam Supply (Ihtikār)}

Rekayasa pasar dalam supply terjadi bila seorang produsen/penjual mengambil keuntungan di atas keuntungan normal dengan cara mengurangi supply agar harga produk yang dijualnya naik. Ihtikār biasanya dilakukan dengan membuat entry barrier, yakni menghambat produsen/ penjual lain masuk ke pasar, agar ia menjadi pemain tunggal di pasar (monopoli). Karena itu, biasanya orang menyamakan ihtikār dengan monopoli dan penimbunan, padahal tidak selalu seorang monopolis melakukan ihtikār. Demikian pula tidak setiap penimbunan adalah ihtikār. BULOG juga melakukan penimbunan, tetapi justru untuk menjaga kestabilan harga dan pasokan. Demikian pula dengan negara apabila memonopoli sektor industri yang penting dan mengusai hajat hidup orang banyak, bukan dikategorikan sebagai ihtikār. Ihtikār terjadi bila syaratsyarat di bawah ini terpenuhi:

1. Mengupayakan adanya kelangkaan barang baik dengan cara menimbun stock atau mengenakan entry-barries.

2. Menjual dengan harga yang lebih tinggi dibandingkan harga sebelum munculnya kelangkaan.

3. Mengambil keuntungan yang lebih tinggi dibandingkan keuntungan sebelum komponen 1 dan 2 dilakukan. (Adiwarman Karim, 2004: 30)

Adapun kemunculan praktek monopoli dapat terjadi dalam berbagai bentuk dan cara:

Pertama, ia dapat terjadi karena memang dikehendaki oleh hukum, sehingga timbullah apa yang disebut sebagai monopoly by law. UUD 1945 pasal 33 juga membenarkan adanya monopoli jenis ini, yaitu dengan memberi monopoli bagi Negara untuk menguasai bumi, air dan kekayaan 
alam yang terkandung di dalamnya serta cabang-cabang produksi yang menguasai hajat hidup orang banyak.

Dengan demikian menurut UUD 1945, sektor yang menguasai hajat hidup orang banyak seperti perlistrikan, air minum, kereta api dan sektorsektor lain yang karena sifatnya yang memberi pelayanan untuk masyarakat dilegitimasi untuk dimonopoli dan tidak diharamkan.

Sayangnya masih banyak pihak yang menyalahartikan maksud mulia yang dikandung UUD 1945, seperti asas kekeluargaan ditafsirkan sebagai "keluarga" sendiri. Sehingga sering kita lihat pada suatu instansi atau perusahaan hanya kerabat mereka saja yang dilibatkan. Pemberian hak-hak istimewa dan eksklusif atas penemuan baru, baik yang berasal dari hak cipta, hak paten, merk dagang, dan lain-lain juga merupakan bentuk monopoli yang di akui undang-undang.

Kedua, monopoly by nature. Yaitu monopoli yang lahir dan tumbuh secara alamiah karena didukung oleh iklim dan lingkungan yang cocok. Kita dapat melihat bentuk monopoli seperti ini yaitu tumbuhnya perusahaan-perusahaan yang karena memiliki keunggulan dan kekuatan tertentu dapat menjadi raksasa bisnis yang menguasai seluruh pangsa pasar yang ada. Mereka menjadi besar karena memiliki sifat-sifat yang cocok dengan tempat dimana mereka tumbuh. Selain itu karena berasal dan didukung bibit yang unggul serta memiliki faktor-faktor yang dominan.

Ketiga, monopoly by licence. Monopoli ini diperoleh melalui lisensi dengan menggunakan mekanisme kekuasaan. Monopoli jenis inilah yang sering menimbulkan distorsi ekonomi karena kehadirannya mengganggu keseimbangan pasar yang sedang berjalan dan bergeser kearah yang diingini oleh pihak yang memiliki monopoli tersebut. (Gunawan Widjaja, 2000: 5-6)

\section{Pematokan Harga (Tas'ir)}

Secara bahasa tas'îr adalah تقدير السعر (mengukur harga). (Ahmad Mustafa, 2003: 220)Sedang secara istilah adalah bahwa seorang penguasa atau wakilnya atau siapa saja dari kalangan pejabat pemerintahan, memberlakukan suatu putusan kepada kaum Muslimin agar mereka menjual barang-barang dengan harga tersebut, dimana mereka dilarang untuk menaikkan atau mengurangi harganya dari harga yang dipatok, demi kemaslahatan umum. (Taqyuddin, 1996: 212) Selanjutnya, ada dua pendapat mengenai penetapan harga ini. Dalam hal ini ada dua masalah. Masalah pertama, tas'îr dalam keadaan stabil, kedua, tas'îr dalam keadaan harga menjulang tinggi.

Masalah pertama, tas'īr dalam keadaan stabil. Pendapat pertama, kebanyakan dari ulama fikih Hanafi, Maliki, Syafi'i dan Hanbali bersepakat tidak bolehnya tas'îr dalam keadaan stabil. Ini bersandar kepada hadis 
yang diriwayatkan oleh Imam Abu Dawud yang meriwayatkannya dari Abu Hurairah.

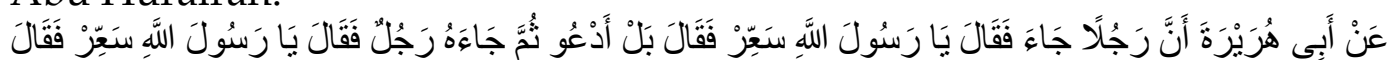

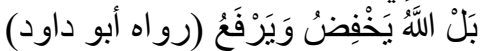

Dari Abu Hurairah, "Bahwa ada seorang laki-laki datang lalu berkata: "Wahai Rasulullah, tetapkanlah harga ini". Beliau menjawab: "(Tidak) justru, biarkan saja". Kemudian beliau didatangi oleh laki-laki yang lain lalu mengatakan: "Wahai Rasulullah, tetapkanlah harga ini". Beliau menjawab: (Tidak) tetapi Allah-lah yang berhak menurunkan dan menaikkan" (HR. Abu Dawud). (Ahmad Mustafa, 2003: 225)

Hadis ini menunjukkan haramnya pematokan harga, dimana pematokan harga tersebut merupakan salah satu bentuk kezaliman yang harus diadukan kepada penguasa agar menghilangkannya. Apabila tersebut melakukannya, maka di sisi Allah dia telah berdosa, sebab dia telah melakukan perbuatan yang haram. Sementara bagi tiap rakyat, berhak mengadukan kepada mahkamah mazhalim (semacam pengadilan tata usaha negara) terhadap tindakan penguasa yang melakukan pematokan harga tersebut. (Taqyuddin, 1996: 212)

Pendapat kedua, seperti diriwayatkan oleh Sa'id bin Musayyab, Rubai'ah bin Abdurrahman, Yahya bin Sa'id al-Ansari mengatakan bahwa tas'îr dibolehkan secara mutlak sekalipun dalam keadaan biasa (stabil). Alasannya, karena tas'îr merupakan kemaslahatan bagi masyarakat dan dengan pematokan harga akan menstabilkan harga, dengan demikian harganya tidak melonjak tinggi. (Ahmad Mustafa, 2003: 225)

Masalah kedua, tas'ir dalam keadaan harga menjulang tinggi. Pendapat pertama, kebanyakan ahli fikih Syafi'i, Hanbali dan Maliki mengatakan bahwa tas'ìr dalam keadaan harga menjulang tinggi tidak diperbolehkan. Mereka berargumentasi dengan hadis-hadis berikut ini.

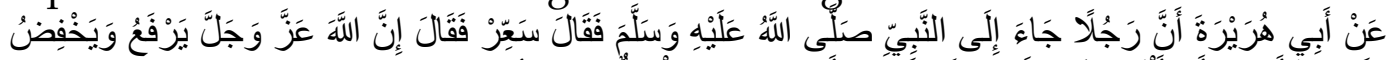

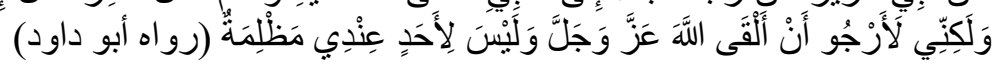

Dari Abu Hurairah, "Bahwa ada seorang laki-laki datang lalu berkata: "Wahai Rasulullah, tetapkanlah harga ini". Beliau menjawab: "(Tidak) justru, biarkan saja". Kemudian beliau didatangi oleh laki-laki yang lain lalu mengatakan: "Wahai Rasulullah, tetapkanlah harga ini". Beliau menjawab: (Tidak) tetapi Allah-lah yang berhak menurunkan dan menaikkan" (HR. Abu Dawud).

Hadis ini menerangkan bahwa tas'îr dianggap sebagai pemaksaan kepada orang-orang agar menjual apa yang mereka miliki tanpa persetujuan dari mereka dan ini merupakan kezaliman bagi mereka.

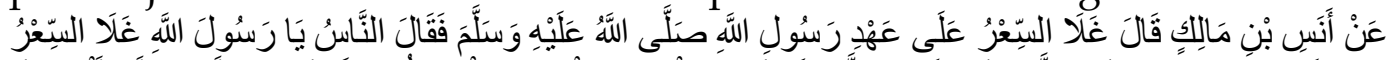

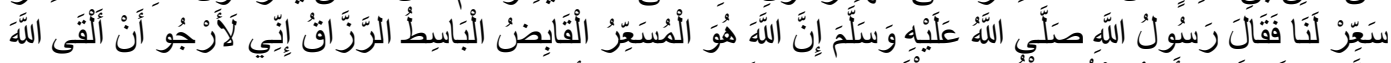

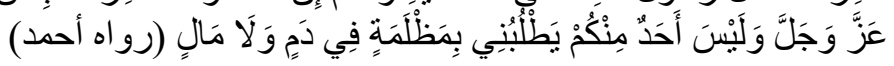

Dari Anas bin Malik berkata: "Harga pada zaman Rasulullah SAW menjulang tinggi". Lalu orang-orang berkata: "Wahai Rasulullah, harga menjulang tinggi, 
tetapkanlah harganya", beliau menjawab: "Sesungguhnya Allahlah Yang Maha Menentukan Harga dan Maha Memberi Rezeki. Aku ingin menghadap ke hadirat Allah, sementara tidak ada satu orang pun yang menuntutku karena suatu kezaliman yang aku lakukan kepadanya, dalam masalah darah dan harta" (HR. Ahmad).

Pada zahirnya hadis ini sebagaimana yang dianut oleh kebanyakan ahli fikih menerangkan bahwa Rasulullah SAW tidak mematok harga sekalipun harganya membumbung tinggi. As-Syaukani menambahkan bahwa secara eksplisit hadis tersebut tidak membedakan antara keadaan harga tidak stabil dan stabil. (Ahmad Mustafa, 2003: 228)

Pendapat kedua, diwakili oleh pengikut Hanafi, sebagian Maliki, Ibnu Taimiyah dan muridnya, Ibnu Qayyim al-Jauziyah, mereka mengatakan bahwa tas'î dibolehkan jika harga naik. Alasannya, sebagaimana dikatakan oleh Shāhib al-Fatāwā al-Hindiyah, "tas'îr" tidak dibolehkan secara ijmak, namun jika pemilik makanan menaikkan harga dan hakim tidak mampu menjaga hak-hak orang muslim kecuali dengan tas' ${ }^{i} r$, maka tidak masalah menetapkan harga sesuai dengan kesepakatan para ahli, dan itu yang harus dipilih dan di fatwakan". (Ahmad Mustafa, 2003: 225)

\section{Analisis terhadap Monopoli dalam Hukum Bisnis Syariah}

Ihtikār dalam perekonomian modern didefinisikan sebagai proses monopoli atas supply dan demand komoditas dengan tujuan untuk mendapatkan keuntungan tertentu. (Al-Misri, 2006: 93) Menurut salah seorang ahli ekonomi Amerika, orang yang melakukan ihtikār menjadikan harta sebagai tujuan hidup, harta adalah segalanya dan tidak diposisikan sebagai fasilitas kehidupan. Dampak monopoli bagi kehidupan ekonomi sudah tidak diragukan lagi, hal ini akan menggiring kerusakan atau bahkan kerapuhan ekonomi. Akan muncul sebuah tindakan eksploitatif orang yang berkuasa terhadap golongan yang membutuhkan, mereka akan dengan mudah menentukan harga sesuai dengan keinginan mereka untuk menumpuk harta. (Al-Misri, 2006: 94)

Banyak negara-negara Muslim seperti Pakistan, telah memperkenalkan hukum-hukum yang menentang monopoli dan praktek dagang yang terbatas. Perhatian negara telah dihubungkan dengan fakta bahwa dengan adanya kekuasaan monopoli dalam industri, pemusatan kekayaan dalam tangan-tangan perusahaan raksasa dan bisnis mereka yang tersebar luas telah menyebabkan praktek-praktek korupsi dan eksploitasi pada konsumen. (Muhammad Abdul Manan, 1992: 154)

Pembahasan masalah monopoli muncul sebagai akibat dari masalah pemberian harga karena persaingan tidak sempurna. Monopoli dapat terjadi dalam beberapa aspek, diantaranya adalah: 
1. Monopoli usaha, yaitu monopoli yang dilakukan perusahaan karena menguasai produksi dan penjualan suatu produk atau jasa secara sendiri/ tanpa saingan di suatu pasar.

2. Monopoli perusahaan, yaitu monopoli yang dilakukan oleh satu kelompok usaha yang terdiri atas beberapa perusahaan yang menghasilkan produk yang relatif sama.

3. Monopoli pangsa pasar, yaitu monopoli yang dilakukan oleh perusahaan yang telah menguasai pangsa pasar di atas $50 \%$ dan perusahaan tersebut menjadi pemimpin harga untuk produk yang sama dihasilkan dan dijual di pasaran. (Muhammad, 2004: 384-385)

Ulama fikih yang melarang tindakan ihtikār menyatakan apabila penimbunan barang telah terjadi di pasar, pemerintah berhak memaksa pedagang untuk menjual barang tersebut dengan harga standar yang berlaku di pasar. Bahkan, menurut mereka barang yang ditimbun oleh para pedagang tersebut dijual dengan harga modalnya dan pedagang tersebut tidak berhak untuk mengambil untung, sebagai hukuman terhadap tindakan mereka tersebut. Kemudian, ulama fikih juga mengatakan bahwa apabila pedagang yang melakukan ihtikār enggan menjual dagangannya sesuai dengan harga pasar, maka hakim berhak menyita barang itu dan membagi-bagikannya kepada masyarakat yang sangat membutuhkan. (Abdul Aziz Dahlan, 1996: 657)

Menurut mereka, pihak pemerintah seharusnya sejak semula telah mengantisipasi agar tidak terjadi ihtikār dalam setiap komoditas, manfaat, dan jasa yang sangat dibutuhkan masyarakat. Untuk itu, pihak pemerintah seharusnya melakukan penetapan harga yang adil pada setiap komoditas yang menyangkut kebutuhan orang banyak. Harga yang adil tersebut, menurut jumhur ulama, adalah dengan mempertimbangkan modal dan keuntungan bagi pedagang serta tidak terlalu memberatkan bagi masyarakat. Bahkan Fathi ad-Duraini berpendapat bahwa pemerintah tidak boleh mengekspor barang kebutuhan warganya sampai tidak ada lagi yang dapat dikonsumsi masyarakat, sehingga membawa mudarat bagi masyarakat. Pada hakikatnya pengeksporan barang yang dibutuhkan masyarakat tersebut sama dengan ihtikār dari segi akibat yang dirasakan oleh masyarakat. (Abdul Aziz Dahlan, 1996: 657)

Pernyataan Fathi ad-Duraini ini didasarkan pada kaidah fikih yang berkaitan dengan fungsi penguasa, yaitu "tasharruf al-imām 'alā ar-ra'iyyah manüthun bi al-mashlahah" (tindakan penguasa harus senantiasa mengacu pada kemaslahatan orang banyak). (Abdul Aziz Dahlan, 1996: 657)

\section{KESIMPULAN}

Dari pembahasan di atas dapat disimpulkan bahwa monopoli dan penetapan harga bisa dilakukan jika keadaan harga di pasaran melonjak 
tinggi. Tentunya, yang lebih berhak mengendalikan monopoli dan penetapan harga adalah penguasa dengan syarat untuk kemaslahatan orang banyak. Monopoli dan penetapan harga pada dasarnya merugikan orang banyak, namun keduanya dapat diberlakukan dalam keadaan terpaksa dan harga tidak stabil. Sehingga, kebutuhan hajat orang banyak dapat teratasi.

\section{DAFTAR PUSTAKA}

Abdul Manan, Muhammad, (1992), Ekonomi Islam: Praktek dan Teori. Terj. Potan Arif Harahap, Jakarta: Intermasa.

Afifi, Ahmad Mustafa, (2003) Al-Ihtikār wa Mauqif asy-Syarì'ah al-Islāmiyyah minhu fi Ithār al-'Ilāqāh al-Iqtishadiyyah al-Mu'ashirah. Al-Qāhirah: Maktabah Wahbah.

an-Nabhani, Taqyuddin, (1996), Membangun Sistem Ekonomi Alternatif; Perspektif Islam. Surabaya: Risalah Gusti.

Dahlan, Abdul Aziz (ed.), (1996), Ensiklopedi Hukum Islam. Jakarta: PT Ichtiar Baru Van Hoeve.

Departemen Pendidikan dan Kebudayaan, (1996), Kamus Besar Bahasa Indonesia. Jakarta: Balai Pustaka.

Karim, Adiwarman, (2004), Bank Islam: Analisis Fikih dan Keuangan. Jakarta: PT RajaGrafindo Persada.

Muhammad, (2004), Ekonomi Mikro Dalam Perspektif Islam. Yogyakarta: BPFE-Yogyakarta.

Qaradawi, Yusuf, (1997), Norma dan Etika Ekonomi Islam. Terj. Zainal Arifin dan Dahli Husin. Jakarta: Gema Insani Press.

Sami, al-Misri Abdul, (2006), Pilar-Pilar Ekonomi Islam. Terj. Dimyauddin Djuwaini. Yogyakarta: Pustaka Pelajar.

Widjaja, Gunawan, (2000), Seri Hukum Bisnis: Anti Monopoli. Jakarta: PT RajaGrafindo Persada.

CD Al-Maktabah as-Syamilah. 